\title{
UK Renal Registry 19th Annual Report: Appendix G UK Renal Registry dataset specification
}

This appendix is available on the UK Renal Registry website only. The current version of this document can be found under the downloads menu at www.renalreg.org/datasets/the-uk-renal-registry-dataset/.

This article is licensed under the Creative Commons AttributionNonCommercial-NoDerivatives 4.0 International License (CC BYNC-ND) (http://www.karger.com/Services/OpenAccessLicense)
UK Renal Registry, Southmead Hospital, Southmead Road, Bristol, BS10 5NB, UK

Email: renalregistry@renalregistry.nhs.uk 
